\title{
Volksraad: Malay Language (Indonesian) as a Means of Political Strategy of National Faction
}

\author{
NazirwanRohmadi \\ Faculty of Teacher Training and \\ Education SebelasMaret University \\ Surakarta, Indonesia \\ Syarif Hidayatullah State Islamic \\ University Jakarta, Indonesia \\ nazirwanr1899@gmail. com
}

\author{
Muhammad Akhyar \\ Faculty of Teacher Training and \\ Education SebelasMaret University \\ Surakarta, Indonesia \\ Syarif Hidayatullah State Islamic \\ University Jakarta, Indonesia \\ makhaliya@yahoo.com
}

\author{
Warto \\ Faculty of Teacher Training and \\ Education SebelasMaret University \\ Surakarta, Indonesia \\ Syarif Hidayatullah State Islamic \\ University Jakarta, Indonesia \\ warto file@yahoo.com
}

\begin{abstract}
History of Indonesia does not reveal many struggles made by the cooperative people in the legislative institution, namely Volksraad. Some members of the Volksraad since 1921 had used Indonesian language as a means of their political struggle. Historical method with discourse analysis approach was used in this research. The historical method has several stages, namely heuristic, critic, analysis, and historiography. Based on the research that had been done, it can be concluded that the use of Malay language as a means of political struggle has a goal to eliminate racial discrimination in the Volksraad. The Malay language used by the National Faction was as affiliation form to the Indonesian who represented by the National Fraction. It was a step to strengthen the political position of the National Faction itself and to show to the Dutch East Indies government that the group was a legitimate representative of the Indonesian. Therefore, the Indonesian language is a form of national identity and as a means to unite nation that must be maintained and should be introduced to the world. This research aims to introduce to the world that politics of Malay Language (Indonesian) have a role to play in realizing the independence of Indonesia.
\end{abstract} Faction

Keywords-Volksraad; Malay Language; and National

\section{INTRODUCTION}

People only recognize the Youth Pledge as a pledge of unity from the youth of Indonesia, truthfully the Youth Pledge is not about that. The Youth Pledge is not only as a pledge but also as a milestone in forming the national identity of Indonesia. It can be see from the whole content of the Youth Pledge, especially the pledge number three about we are the sons and daughters of Indonesia uphold the unity language of Indonesian [1]. The pledge is a step to make Indonesian as the language of unity and struggle. It causes the emerge of excessive pride when using Indonesian rather than Dutch or local language [1].

Long time before the Youth Pledge was vowed, Jahja Datoek Kajo and Haji Agus Salim used Malay language consistently in every speech held in Volksraad. The use of Malay language in Volksraad then was continued by National Fraction formed in 1930. Therefore, this research uses historical research method and the approach of discourse analysis. The data obtained are Soeara Parindra magazine, the speech of Volksraad members, and the regulation of Dutch East Indies Government.

This research focuses the study on the use of Malay language by the member of Volksraad who represented the nation. Therefore, this research has differences with the previous research. Some of previous researches conducted were wide with the study of Malay language in Dutch East Indies. Some of the researches are finding language, creating language: the language: politic and nationalism of Indonesia which was studied by Hilmar Farid and The politic of language in Dutch East Indies which was studied by Kees Groeneboer. This research is expected to complete the repertoire of Indonesian political knowledge from the historical point view. So that, it can provide knowledge the importance of Indonesian in the society and state life.

\section{METHOD}

This research uses historical research methods with the stages of Heuristic, Critic, Analysis, Historiography [2]. The method is helped by the approach of discourse analysis. The discourse analysis used because it can help this research to watch the discourse (the use of language in the form of oral and written) as the form of social practice [3]. According to Titscher [4], Discourse analysis is interpretative and explanatory. Discourse analysis implies the existence of a systematic methodology and the relation between text and social conditions, ideology, and power relations. Discourse refers to a unit of language larger than a sentence, and discourse analysis is the study of these sequences of sentences [5]. It can help this research to know used Indonesian language in Volksraad. This research uses primer sources from Soeara Parindra magazine, the speech of Volksraad member, and the regulation of Dutch East Indies government.

\section{RESULT AND DISCUSSION}

Volksraad is a legislative institution formed on May, 181918. This institution has 38 members with 15 people of Indonesian representatives, the number of members increased to 49 members with 20 people of Indonesian representatives in 1920, and the number of members increased to 61 people with 25 people of Indonesian representatives in 1925 [6]. Volksraad had various of unique legislative regulations, one of them was required to use Dutch language in every speech session in meeting room [7]. The 
representative of Indonesia who firstly used Indonesian to oppose the regulation was Haji Agus Salim. Agus Salim became the Volksraad member with the tenure of 1921-1923. His first speech in Volksraad talked about the economical condition of Dutch East Indies by using Malay language which then was opposed by one of the Volksraad member from European representative. The European representative stated that you stopped Malay language because Malay language in economical field could not be translated. The statement then was replied by Agus Salim by saying "firstly try to translate the word of economic in your Dutch" [8]. The statement stated by the European representative was a form of marginalization of Indonesian language.

The note on the use of Indonesian in Volksraad by Agus Salim was very limited. It was because Agus Salim's tenure lasted only 3 years and the Volksraad meeting was only held twice a year [9]. Indonesian was used again as the political speech by Jahja Datoek Kajo. Jahja Datoek Kajo had becomethe Volksraad member since 1927 to 1939 . It caused Jahja Datoek Kajo awarded the title "the Master of Indonesian Language" in Volksraad by Bumiputera magazines [10]. The spirit of Jahja Datoek Kajo in using Indonesian was due to the pride in himself as an Indonesier [10]. Jahja Datoek Kajo who gave a speech by using Indonesian was often considered to have insufficient knowledge of Dutch. However, he could answer the responses given by using Dutch through Indonesian well [10]. Jahja Datoek Kajo is also a member of National Fraction formed in 1930 with the purposes of the Independence of Indonesia [11]. The national fraction used Indonesian language in 1938 after the refusal of Soetardjo's petition and the results of the First Indonesian Congress which was the political demonstration of Indonesian [12]. The national fraction was aware that language is a means of political struggle to seize independence and an identity of a nation.

The chairman of national fraction is Mohammad Husni Thamrin who gave speech by using Indonesian strongly criticized the policy Dutch East Indies government which never appointed people from Indonesia to be Burgemeester (Mayor). The government did not give the position because the government thought the indigenous had not had adequate capabilities yet. The answer then was responded by Thamrin [13] by saying that "not competent yet!" How poor Indonesian children who were not competent enough although they had been in cooking pots. The language spoken by Thamrin was the expression of his anger to the government. It was because in some of his speech, Thamrin often got government's answer with the indefinite indigenous phrases. Even in 1934, the phrase of eating first and then having politics were very well known by Volksraad who represented Indonesia [14]. The phrase had appeared since 1930 and was the form of phrases that degraded the capability of Indonesian. In fact, many of intellectuals of Indonesian had higher education and had capacity to be a mayor.

Thamrin [13] continues his speech by saying if a nation is cooked for so long and it is not ripe yet, is it wrong to cook or a chef? How a pity Indonesian children! The sentence issued by Thamrin is a form of reply and coarse innuendo to the Dutch East Indies government. This is because the government and Volksraad members who represent the Dutch people often analyze the Indonesian nation is a child who must be guided by his mother who is a Dutch [15]. The government statement was more frequently pronounced when Soetardjo's petition was submitted. The analogy is denied by the representatives of Indonesia nation by saying that the child will be mature and given life independently by his mother? Though the boy has been guided for 300 years! [15].

The sentence back each other is inseparable from the economic situation of the Indonesian nation is getting worse due to the crisis in 1930 and second world war danger. The government even provides a heavy tax burden on the Indonesian nation to face the threat of Second World War. When the Second World War broke out, the Dutch central government fells into Germany in July 1940 and it forced Queen Wilhelmina to flee to England [16]. The momentum was exploited by the National Fraction by filing several demands. One of the National Fraction demands is the replacement of Inlander's designation into Indonesia, Indonesier, or Indonesisch. According to the National Faction, the word Inlander is a painful term for the Indonesian nation, as the Dutch name for the Dutch nation [17]. The word Inlander for the Indonesian nation is a derogatory term for the Indonesian nation, because it comes from the point of view of the colonist. Not only that, the purpose of Indonesian word using is eliminating racial differences that have three groups, they are Europe, eastern foreign, and native. This is done so all the people who live in Indonesia and earn a living can love their country regardless of race difference.

The demands were met by the Dutch central government after fleeing to Britain. However, the government rejected the Indonesian word, the government only allows the use of the word Indonesier or Indonesisch. In the midst of the Second World War in Europe and East Asia and the fierce debates in the Volksraad, Japan apparently had infiltrated the economy to the Dutch East Indies since 1930. It is done in order to win the heart of Indonesian nation to take sides to Japan. The infiltration was done by flooding cheap goods from Japan to the Dutch East Indies. In addition, Japan spreads its intelligence agents throughout the Dutch East Indies. They are disguised as grocery traders and journalists [18].

The flood of goods and intelligence agents who are good at communicating with the people make a Japanese military analyst says that the Dutch-ruled nation cannot advance anymore, because he does not know the oppressed Indonesian situation and know the intelligence of Indonesian brain [14]. The sentence is known and realized by the National Fraction members. The statement is reinforced by the state of society that has been taken by the Japanese heart. Due to the infiltration of Japanese economy, people are familiar with the term DJINTAN (Djendral Japan Itoe Nanti Toeloeng AnakNegri) [14]. Thamrin, who often reminds the government of Indonesian nation state and the Japanese infiltration was regarded as a man who supported the Japanese power in the Dutch Indies.

The accusation is not surprising refer to the words of a National Fraction members who said that the Dutch representatives did not want to feel the suffering of Indonesian people, they just wanted to go back to the Netherlands and be able to rise their position! [15]. 
The Dutch representatives do not even have extensive knowledge of Indonesian language. It can be reviewed on the suggestion issued by the Governor of East Java, Van der Plas who said that the Dutch people must learn the Indonesian language to know the feelings and thoughts of the Indonesian nation [19]. The statement is in accordance to the meaning and function of the language, language can be used to convey thoughts, ideas, and feelings, both actual and imaginary [20]. The majority of the Dutch people only learn languages that are degrading to the Indonesian people, as the slave is often used by the Dutch people when sending bumiputera servants to serve them. Therefore, the Dutch will never understand the Indonesian nation feelings.

Based on the above explanation, the use of the Indonesian language within the National Fraction has the power of language in the status category of a person, race, desire, and affiliation [21]. It can be found when people who use Malay language are considered to a low social class, while people who use the Dutch language have a high social class. These circumstances led to the language discrimination. The language discrimination was also evident in the Dutch East Indies education. Dutch language education is only given to schools with the first class of ELS (Europeesche Lagere School) and HBS (Hogere Burger School). The majority of the students are Dutch and children from a Bumiputera official. However, some children of the Bumiputera officials can hone their knowledge and hearts, so they can produce reading material through mass media for their nation. The article is used by intellectuals to propagandize independence by holding open rallies. The general meeting is attended by people with very little access to education. Therefore, the Indonesian intellectuals provide knowledge through puppet stories, fairy tales, and prophecies [22].

According to Anderson [23] the vehicle for understanding science cannot be the Dutch language; and then the attack vehicle is Indonesian (Revolutionary Malay). This was in accordance with the opinion about the relation of power that is conveyed by Michel Foucault stating that the power to produce knowledge and knowledge provides power [24]. Therefore, the reading material was regarded as a wild reading by the Dutch East Indies government [23]. Even schools established by Indonesian intellectuals are branded as wild schools. The wild school teaches Dutch to Bumiputera. It is done with the aim to provide insight into the knowledge of Dutch language and open new insights for Bumiputera. The steps are also a form of equal rights to education and equalize Dutch with Malay language. Therefore, there is no more education and language discrimination for Bumiputera. Therefore, schools founded by Indonesian intellectuals are labeled as wild schools. This was done by the government because the educational results provided by the Dutch resulted in the rebels and had deviated from their initial goal of creating cheap labor [25].

The discrimination of language then developed into racial discrimination. It is caused by Malay language is used by the Indonesian people who are considered to have low social status. Malay language used by the National Faction is a form of affiliation to the people of Indonesia represented by the National Faction group. It was a move to strengthen the political position of the National Faction and to demonstrate to the Dutch Indies government that the group was a legitimate representative of the Indonesian nation.

\section{CONCLUSION}

The Indonesian language used by the National Faction has the effect of strengthening the unity of ethnicity as well as the tool of political struggle within the National Fraction. According to Gavin and Mathiot [26] language can have a unify and separate functions. Language unification is formed on the basis of the feelings of individual citizens, thought different ethnicities. It arises because of the use of similar language. The statement is inseparable from the relationship of language, mind and culture that affect each other. So it can be concluded that a nation that different language from other nations, will have different culture and way of thinking [20].

Therefore, the Indonesian language that has a long historical background, it should be proud of Indonesia people because it has a variety of functions and identity. Even the Indonesian language should be introduced to the world, especially from the point of view of the historical process of choosing Malay as Indonesian. It is expected that the study of language politics from a historical point of view will be more emerging. There is still a lot of empty space in the historical study of language politics in Indonesia.

\section{REFERENCES}

[1] A. G. Martha, Pemuda Indonesia: Dalam Dimensi Perjuangan Bangsa. Jakarta: Purbasari, 1984.

[2] Kuntowijoyo, Pengantar Ilmu Sejarah. Yogyakarta: Yayasan Bentang Budaya, 2001.

[3] Eriyanto, Analisis Wacana. Yogyakarta: LKiS, 2001.

[4] S. Titscher, Metode Analisis Teks \& Wacana. Yogyakarta: Pustaka Pelajar, 2009.

[5] I. Jansen, "Discourse Analysis and Foucault's Archaeology of Knowledge" International Journal of Caring Sciences, vol. 1, no. 3, pp. 107-111,2008.

[6] W. H. Helsdingen, Pekerdjaan Dewan Ra'jat Sepoeloeh Tahoen. Batavia: Balai Poestaka,1928.

[7] J. Riphagen, Atoeran Pemerintahan Hindia Belanda.Batavia: Balai Poestaka, 1927.

[8] Tempo, Agus Salim: Diplomat Jenaka Penopang Republik. Jakarta: Gramedia,2013.

[9] R. K. Poerbopranoto, Dewan Ra'jat. Batavia: Balai Poestaka, 1938.

[10] A. Etek, dkk, Kelah Sang Demang Jahja Datoek Kajo. Yogyakarta: LKiS, 2008.

[11] Suhatno, dkk, Tokoh-Tokoh Pemikir Paham Kebangsaan. Jakarta: Departemen Pendidikan,1995.

[12] S. Muljana, Kesadaran Nasional: Dari Nasionalisme Sampai Kemerdekaan. Yogyakarta: LKiS, 2008.

[13] M. H. Thamrin, "Burgemeester Indonesia" Soeara Parindra, pp. 201202, 1938.

[14] M. H. Thamrin, Algemeene Beschouwingen in den Volksraad op 13 Juli 1934. Batavia: Volksraad, 1934.

[15] A. Salim, Berdiri Sendiri: Usul Petisi Soetardjo CS dan Para Pembitjaraan dalam Volksraad. Batavia: Firma.H. F. Boersma, 1936.

[16] E. Moechtarman, "Bagaimanakah Nederland Didoedoeki Moesoeh" Soeara Parindra, pp. 163-167, 1940.

[17] M. H. Thamrin, "Seboetan Indonesia dalamVolksraad"Soeara Parindra, pp. 256-259, 1940.

[18] A. Yusra, Hoegeng: Polisi Idaman dan Kenyataan (Sebuah Autobiografi). Jakarta: Pustaka Sinar Harapan, 1993.

[19] Soeroso, "Hindia Haroes Banjak Bersifat Belanda Perhoeboengan Antara Belanda dan Djawa Adalah Penting Sekali” Soeara Parindra, pp. 127- 
$132,1940$.

[20] A. Chaer, Sosiolinguistik: Perkenalan Awal. Jakarta: Rineka Cipta, 2010.

[21] A. M. Yaqin, Pendidikan Multikultur: Untuk Demokrasi dan Keadilan. Yogyakarta: Pilar Media, 2005.

[22] Soekarno, Dibawah Bendera Revolusi. Djakarta: Panitia Penerbit, 1962.

[23] Y. Latif, Bahasa dan Kekuasaan. Bandung: Mizan, 1996.

[24] Sutrisno, dkk, Teori-Teori Kebudayaan. Yogyakarta: Kanisius, 2005.

[25] K. Groeneboer, "Politik Bahasa Pada Masa Hindia Belanda" Wacana, pp. 32-48, 1999.

[26] Sumarsono, Sosiolinguistik. Yogyakarta: Pustaka Pelajar,2013. 